УДК 621.438-712.8

Д. В. КОНОВАЛОВ, Г. О. КОБАЛАВА

Херсонська філія Національного університету кораблебудування імені адмірала Макарова, Украӥна

\title{
ПРОМІЖНЕ ОХОЛОДЖЕННЯ ЦИКЛОВОГО ПОВІТРЯ В ГАЗОТУРБІННИХ УСТАНОВКАХ АЕРОТЕРМОПРЕСОРАМИ
}

\begin{abstract}
Проведено аналіз існуючих технологій підвищення паливно-енергетичної ефективності газотурбінних установок за рахунок проміжного охолодження ииклового повітря та наведено переваги технології охолодження аеротермопресором. Застосування иього апарату для охолодження компресорного повітря дозволяє: компенсувати аеродинамічні втрати по повітряному тракту і зменшити роботу на стиснення в компресорі, збільшити витрату робочого тіла $i$, як наслідок, збільшити потужність ГТУ. Визначено задачі для забезпечення раџіональної організації прочесів охолодження в аеротермопресорі, що, у свою чергу, дозволить досягнути оптимальних параметрів підвищення коефіцієнта корисної дії ГТУ та зменшення питомої витрати палива відносно змінних кліматичних умов експлуатації.
\end{abstract}

Ключові слова: газотурбінна установка, охолодження ичилового повітря, термогазодинамічна компресія, аеротермопресор.

\section{1. Аналіз проблеми і постановка мети дослідження}

На теперішній час газотурбінні установки (ГТУ) знайшли широке розповсюдження у якості теплових двигунів для авіаційної, суднової та стаціонарної енергетики завдяки модульності конструкцій, пристосованості до автоматизації, високій надійності та технологічності.

ГТУ простої схеми (рис. 1) мають порівняно невисоку теплову економічність. Це пов'язано, насамперед, 3 тим, що велика частина потужності $(40 \ldots 60 \%)$, що виробляється турбінами, витрачається на привід ступенів компресора. Витрата потужності тим більша, чим вище температура повітря навколишнього середовища, що надходить в компресор [1-3]. Зростання температури зовнішнього середовища на кожен $1{ }^{\circ} \mathrm{C}$ призводить до зменшення вихідної потужності ГТУ на 0,5 ...0,9 \% [4].

Одним із шляхів покращення експлуатаційних характеристик ГТУ, підвищення потужності та зменшення витрати палива $є$ перехід до складного циклу. Існують наступні способи підвищення ефективності циклів ГТУ [2]:

1) проміжний підігрів газу в процесі розширення;

2) проміжне охолодження повітря в процесі підвищення тиску;

3) регенерація теплоти відхідних газів ГТУ;

4) утилізація теплоти відхідних газів ГТУ в паротурбінному теплоутилізаційному контурі;

5) утилізація теплоти відхідних газів ГТУ з ор- ганізацією її роботи за контактним газопаротурбінним циклом.

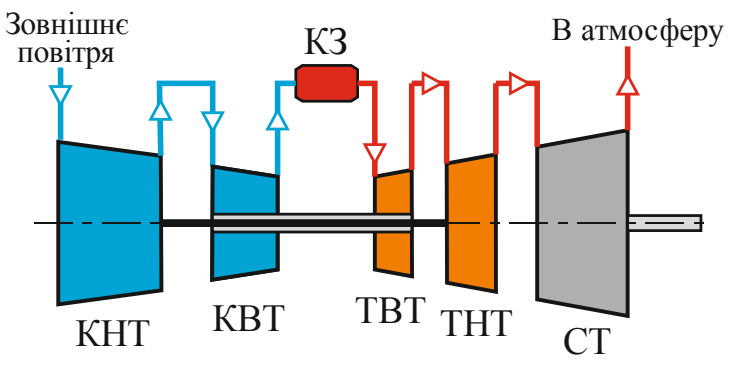

Рис. 1. ГТУ простої схеми:

КНТ - компресор низького тиску; КВТ - компресор високого тиску; КЗ - камера згоряння;

ТВТ - турбіна високого тиску; ТВТ - турбіна низького тиску; СТ - силова турбіна

Серед наведених способів підвищення ефективності ГТУ одним з перспективних є застосування проміжного охолодження в процесі стиснення в компресорі, тобто підвищення ефективності роботи компресора шляхом ізотермування процесу стиснення повітря (наближення кінцевої температури стиснення до початкової). Звідси, без втрати потужності знижується температура газів на вході в турбіну, що сприятливо позначається на ресурсі ГТУ або 3'являється можливість підвищити потужність ГТУ без зниження ресурсу їі роботи [1].

Зважаючи на це, актуальним напрямом підвищення економічності ГТУ можна вважати впровадження енергозберігаючих технологій, які забезпе- 
чать утилізацію низькопотенційної теплоти вторинних енергетичних ресурсів (ВЕР) і компенсують негативний вплив температури навколишнього середовища на паливно-енергетичну ефективність ГТУ. До таких технологій можна віднести проміжне контактне охолодження циклового повітря аеротермопресором, в основу якого покладено процес термогазодинамічної компресії [5]. Особливістю цього процесу є підвищення тиску в результаті миттєвого випаровування дрібно-диспергованої рідини, що упорскується в прискорений до швидкості звуку повітряний потік [6]. Завдяки збільшенню тиску скипаючої рідини зменшуються витрати потужності на стискання робочого тіла (циклового повітря), підвищується ККД і зменшуються витрати паливноенергетичних ресурсів ГТУ. Відмінністю запропонованої технології $\epsilon$ те, що вона забезпечує за рахунок інтенсивних тепло-масообмінних процесів і високих швидкостей в аеротермопресорі ефективне дрібно-дисперсне розпилення рідини. Це, у свою чергу, при упорскуванні понад необхідної кількості рідини для випаровування, призведе до більш ефективного випаровування крапель, що залишились в потоці повітря, при стисканні в компресорі високого тиску та, відповідно, створить необхідні умови щодо ізотермування процесу стиснення.

Мета дослідження - обгрунтувати підвищення паливної-енергетичної ефективності ГТУ за рахунок технології проміжного охолодження циклового повітря аеротермопресором, яка полягає у використанні теплового потенціалу ВЕР для прискорення повітряного потоку до швидкості, близької звуковій і випаровування води при мінімальному аеродинамічному опорі, а також забезпеченні ефективного дрібно-дисперсного розпилення рідини на вході компресора високого тиску.

\section{2. Результати дослідження}

Проміжне охолодження циклового повітря ГТУ можливо здійснити, принаймні, двома шляхами [7]:

1) зовнішнім охолодженням, тобто через поверхню теплообміну (рис. 2). Таке охолодження можна здійснити, об'єднуючи ряд послідовних ступенів компресора $з$ установкою в проміжках повітряного тракту теплообмінників. Зовнішне охолодження повітря скорочує роботу стиснення, але в той же час безповоротно виводить частину теплоти з циклу;

2) змішуванням циклового повітря 3 диспергованою водою, тобто упорскування води у вигляді крапель на вході компресора або по його тракту між ступенями. При цьому краплі води, що випаровуються відводять теплоту від повітряного потоку, охолоджуючи його [7].
В ГТУ із зовнішнім проміжним охолодженням повітря, з високою температурою після ступеня або частини ступенів компресора, охолоджується водою у проміжному поверхневому теплообмінникуохолоджувачі та надходить до другої частини компресора (рис. 2).

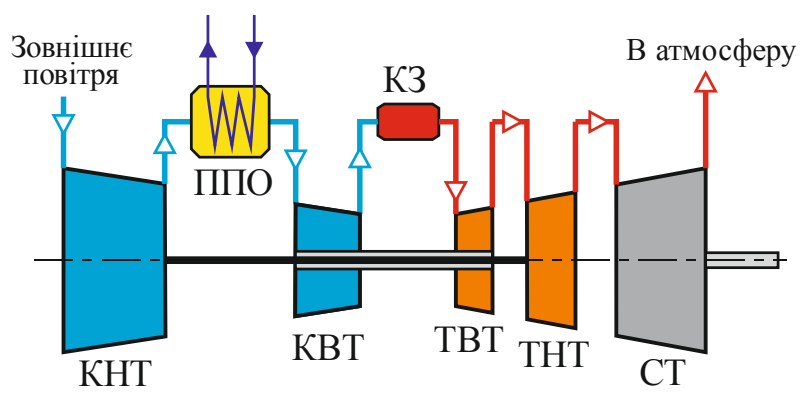

Рис. 2. ГТУ з проміжним охолодженням повітря в поверхневому повітроохолоджувачі:

ППО - поверхневий повітроохолоджувач

На рис. 3 наведено термодинамічний цикл такої ГТУ в $\mathrm{T}(\mathrm{S})$-координатах (температура-ентропія). Особливістю даного циклу, на відміну від циклу ГТУ простої схеми (рис. 1), є те, що процес підвищення тиску повітря в компресорі носить ступінчастий характер. В даному циклі: процес 1-2 - політропне стиснення повітря в першому ступені компресора; процес 2-3 - охолодження повітря водою в проміжному повітроохолоджувачі; процес 3-4 - політропне стиснення повітря в другому ступені компресора; 4-5 - підвід теплоти в камері згоряння при практично постійному тиску; 5-6 - політропне розширення газу в ступенях турбіни; 6-1 - умовний процес, що замикає цикл.

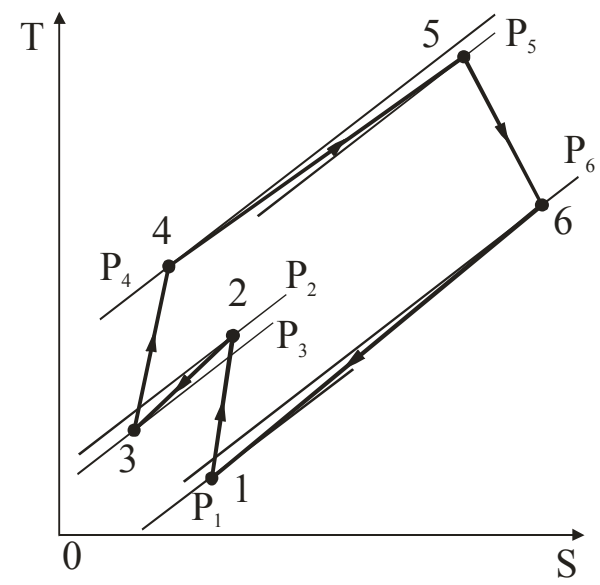

Рис. 3. Термодинамічний цикл ГТУ $з$ проміжним охолодженням повітря в поверхневому повітроохолоджувачі

В процесі охолодження температура повітря знижується до температури $\mathrm{T}_{3}$, яка може бути 
$\mathrm{T}_{3} \leq \mathrm{T}_{1}$. При цьому величина недоохолодження може складати $\Delta_{\mathrm{ox}}=\left(\mathrm{T}_{3}-\mathrm{T}_{1}\right)=5 \ldots 35^{\circ} \mathrm{C}$ [2]. Тиск повітря на вході в другий ступінь компресора $\mathrm{P}_{3}$ буде меншим, ніж тиск нагнітання $\mathrm{P}_{2}$ в першому ступені через аеродинамічні втрати тиску в проміжному повітроохолоджувачі. Такі втрати тиску складають за різними оцінками $\Delta \mathrm{P}_{1}=\left(\mathrm{P}_{2}-\mathrm{P}_{3}\right)=3,0 \ldots 3,5$ кПа.

Застосування проміжного охолодження в ГТУ iз поверхневими повітроохолоджувачами дозволяє досягати значень ККД в $32 . .38$ \% при питомій потужності відповідно $180 \ldots 300$ кВт/(кг/с) [2], при цьому ступінь підвищення тиску в компресорі для сучасних ГТУ складає $\pi_{\mathrm{\kappa}}=25-32$.

Розглянемо особливості застосування проміжного охолодження циклового повітря в ГТУ.

В газотурбінному агрегаті (ГTA) WR-21 (Rolls Royce) $з$ метою підвищення ефективності були застосовані сумісне проміжне охолодження повітря між компресорами та регенерація теплоти відпрацьованих газів. Схема проміжного охолодження циклового повітря - двоконтурна. Перший контур повітроохолоджувача вписаний у конструкцію агрегату, що забезпечує мінімальні втрати тиску повітря при проходженні його через теплообмінні поверхні. Основними елементами повітроохолоджувача $\epsilon$ п'ять теплообмінних пластинчастих матриць, виготовлених з мідно-нікелевого сплаву.

В ГТА "Надєжда" використано регенератор в основному циклі, а також охолодження повітря між компресорами і підігрів мережної води в утилізатоpi. Застосування такої теплової схеми дозволяє збільшити ККД агрегату до 44 \%. Сумарний гідравлічний опір повітроохолоджувача складає $2 \%$ [3].

Застосування проміжного охолодження в LMS100 (General Electric) дозволило збільшити ступінь підвищення тиску повітря до $\pi_{\kappa}=40$, і початкову температуру газу $\mathrm{T}_{\text {г1 }}=1653 \mathrm{~K}$ при цьому ККД склав $\eta_{\mathrm{e}}=45,5 \%$.

Іншим перспективним способом проміжного охолодження циклового повітря є контактне охолодження шляхом розпилення води через форсунки (рис. 4) [4, 7, 8].

Так, в основі технології НАТ (Humidified Advanced Turbine) лежить використання вологого повітря в циклі ГТУ шляхом упорскування води після компресора. Більш досконалою є технологія багатоступінчатого стиснення повітря та розширення газу - CHAT (Cascaded Humidified Advanced Turbine). Також до перспективних технологій слід віднести газопаротурбінну технологію "Водолій" (ДП НВКГ "Зоря-Машпроект") і SPRINT (ГTА марки LM6000 PC).

Система WAC (Hitachi) за рахунок упорскування води в проточну частину компресора дозволяє на $5 \ldots 10 \%$ збільшувати потужність ГТД в найбільш складних кліматичних умовах [4].

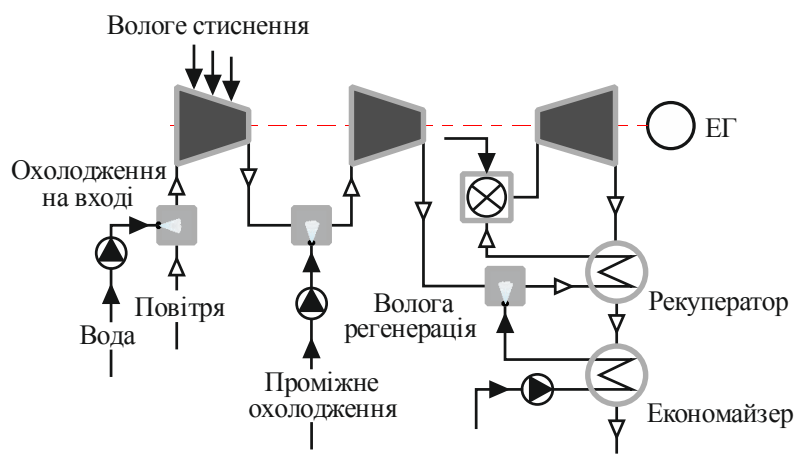

Рис. 4. Узагальнююча схема упорскування води (пари) на різних етапах по тракту ГТУ

Застосування контактного охолодження циклового повітря має ряд переваг на відміну від поверхневого. До таких переваг слід віднести: підвищення потужності ГТД за рахунок збільшення витрати робочого тіла; більше підвищення ККД за рахунок більш низького охолодження циклового повітря; зменшення викидів оксидів азоту (екологічне зволоження).

Одним із перспективних способів контактного проміжного охолодження циклового повітря ГТУ $є$ використання струминних апаратів. Такими апаратами називаються пристрої, в яких здійснюється процес інжекції, що полягає в передачі кінетичної енергії одного із потоків іншому, шляхом безпосереднього контакту (змішування). Струминні апарати мають ряд переваг, що робить їх цілком конкурентоспроможними порівняно з механічними способами упорскування води (форсунки), традиційними теплообмінниками та іншими пристроями [9]:

1) відсутність рухомих частин;

2) повна герметичність та висока надійність;

3) простота у виготовленні та обслуговуванні;

4) здатність працювати без приводу енергії 33овні.

Для забезпечення ефективного контактного проміжного охолодження циклового повітря ГТУ можливе використання такого струминного апарату як аеротермопресор [10].

Аеротермопресор - це двофазний струминний апарат для контактного дисперсного охолодження, в якому за рахунок відведення теплоти від газового потоку відбувається підвищення тиску газу та його охолодження. При відповідній організації процесів випарного контактного динамічного охолодження виникає ефект термогазодинамічної компресії (термопресіі) - явище, при якому відбувається підвищення тиску газу в процесі миттєвого випаровування води, упорскуваної в газовий (повітряний) потік, 
прискорений до швидкості, близької звуковій. При цьому на випаровування води відводиться теплота від газу (повітря), в результаті чого знижується його температура. Окрім того, при упорскуванні рідини понад необхідної кількості для випаровування, аеротермопресор буде здійснювати ефективне розпилення рідини перед компресором високого тиску, що, у свою чергу, дає можливість забезпечити ефективне довипаровування рідини в ступенях компресора (ізотермування процесу).

На рис. 5 зображена принципова схема аеротермопресора найпростішої конструкції 3 випарним охолодженням газу, який складається з сопла 1, в якому газ, який має досить високу температуру, прискорюється та набуває додатковий запас кінетичної енергії, системи упорскування 2, за допомогою якої в потік гарячих газів вводиться охолоджуюча рідина, секції випаровування 3 , де велика частина рідини випаровується, а газ інтенсивно охолоджується, і дифузора 4, призначеного для зменшення швидкості утвореної парогазорідинної суміші.

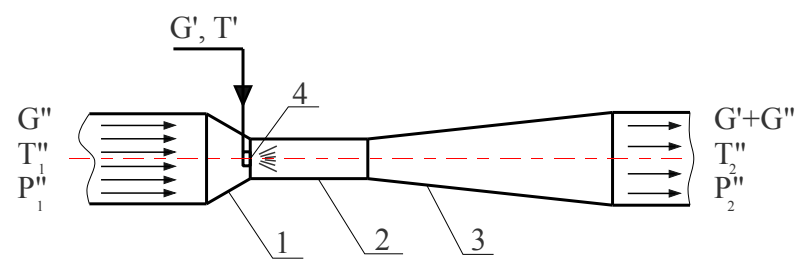

Рис. 5. Схема аеротермопресора з випарним охолодженням:

1 - конфузор (сопло); 2 - камера випаровування;

3 - дифузор; 4 - форсунка для розпилення води

Підвищення повного тиску в аеротермопресорі може бути досить значним і складати за різними оцінками 5...30\% \%6].

Наведений аналіз розглянутих технологій дає змогу стверджувати, що застосування аеротермопресора для контактного проміжного охолодження циклового повітря ГТУ забезпечить ефективне дрібно-дисперсне розпилення рідини в потоці повітря 3

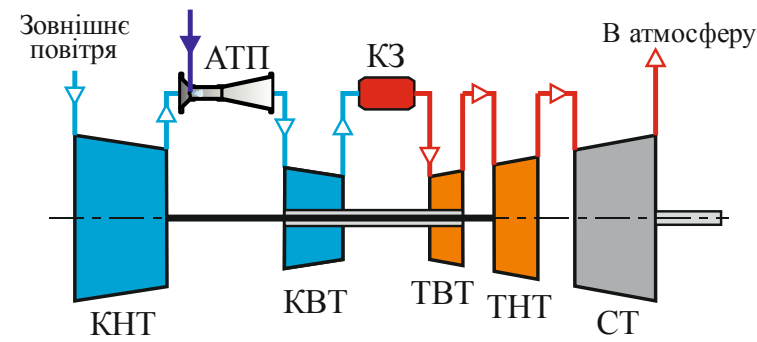

a) одного боку і певне збільшення тиску цього потоку 3 іншого. Зважаючи на це, розглянемо більш детально можливі варіанти застосування аеротермопресора у складі ГТД.

Встановлення проміжного охолоджувача повітря в ГТУ можливо двома способами [2]: 1) між ступенями високого та низького тиску компресора; 2) між ступенями компресора низького тиску. При застосування другого способу, компресор по суті $\epsilon$ не двох, а трьохступінчастим, причому перша (низького тиску) і друга (середнього тиску) ступені компресора приводяться однією турбіною низького тиску.

За аналогічними схемами можливо встановити i аеротермопресор. Схема із встановлення аеротермопресора між ступенями компресора (високого i низького тиску) наведена на рис. 6, a, і схема iз встановленням аеротермопресора між ступенями компресора низького тиску наведена на рис. 6, б.

На рис. 7 показано теоретичний термодинамічний цикл такої ГТУ. Особливістю такого циклу є те, що процес охолодження повітря 2-3а супроводжується не зниженням тиску (в наслідок аеродинамічного опору), а його підвищенням на $\Delta \mathrm{P}_{\text {тп }}=\left(\mathrm{P}_{3 \mathrm{a}}-\mathrm{P}_{2}\right)$. 3 циклу можна побачити, що охолодження в аеротермопресорі можливо до температури дещо вищої $\left(\mathrm{t}_{3 \mathrm{a}}=50 \ldots 70^{\circ} \mathrm{C}\right)$ ніж в поверхневому повітроохолоджувачі, де температура повітря на виході із урахуванням недоохолодження буде становити $\mathrm{t}_{3}=25 \ldots .50{ }^{\circ} \mathrm{C}$.

Але слід відзначити, що охолодження в аеротермопресорі супроводжується підвищенням тиску, що дає можливість компенсувати аеродинамічні втрати в порівнянні зі схемою на рис. 2 і навіть трохи збільшити цей тиск. Розрахунки показують можливість збільшення тиску на $\Delta \mathrm{P}_{\text {тп }}=\left(\mathrm{P}_{3 \mathrm{a}}-\mathrm{P}_{2}\right)=$ $=4 \ldots 12 \%$ (рис. 8 ). 3 рис. 7 видно, що площа фігури, яка обмежує процеси циклу, у випадку із охолодженням аеротермопресором буде більше, ніж з поверхневим повітроохолоджувачем, тобто $\mathrm{S}_{1-2-3 \mathrm{a}-4 \mathrm{a}-5-6}>\mathrm{S}_{1-2-3-4-5-6}$, що свідчить про збільшення

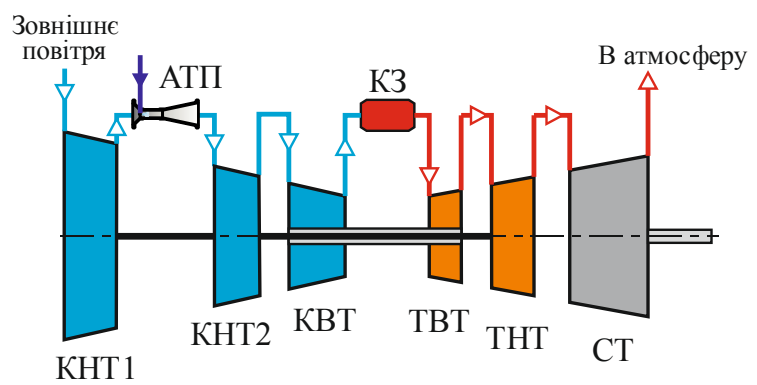

б)

Рис. 6. Схема ГТУ з проміжним охолодженням повітря в аеротермопресорі між ступенями низького та високого тиску в компресорі (а) і між ступенями компресора низького тиску (б):

КНТ - компресор низького тиску; АТП - аеротермопресор; КВТ - компресор високого тиску; КЗ - камера згоряння; ТВТ - турбіна високого тиску; ТНТ - турбіна низького тиску; СТ - силова турбіна 
ККД циклу, i може становити $\Delta \eta_{\mathrm{e}}=1,0 \ldots 2,0 \%$ (рис. 8).

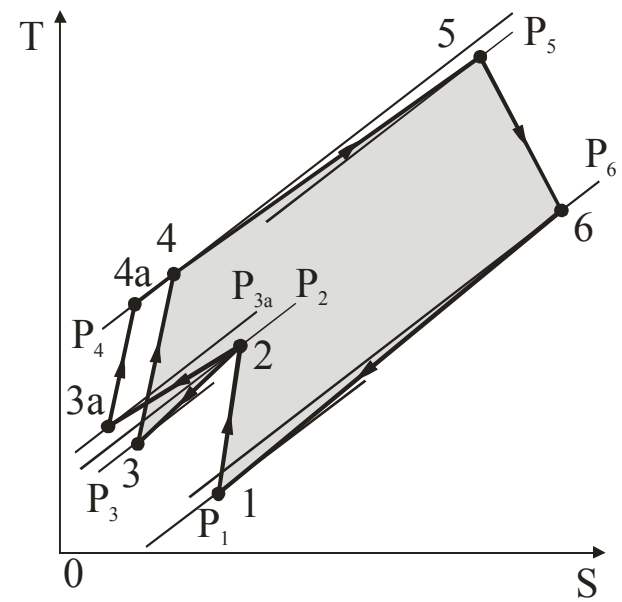

Рис. 7. Термодинамічний цикл ГТУ $з$ проміжним охолодженням повітря в аеротермопресорі

Враховуючи доцільність наведених на рис. 6 схем, можна запропонувати схему (рис. 9), що поєднає обидва способи встановлення аеротермопресора по тракту компресора ГТУ.

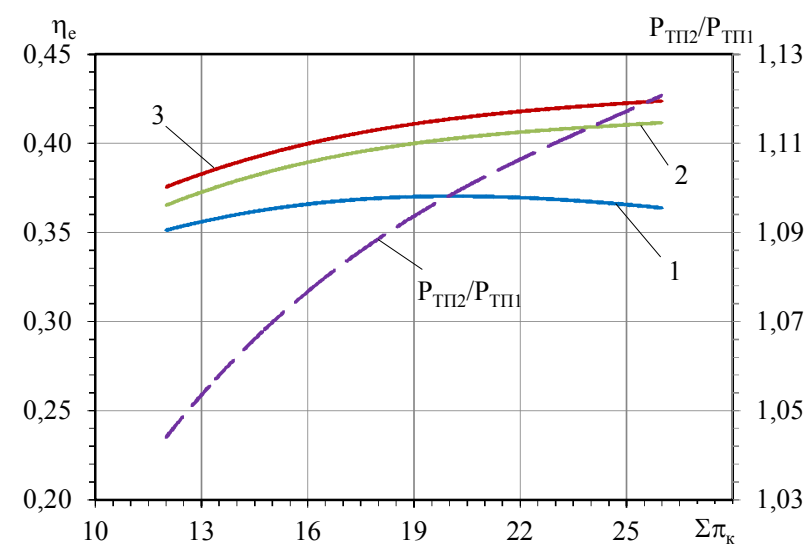

Рис. 8. Залежності ККД циклу ГТУ $\eta_{\mathrm{e}}$ і відносного підвищення тиску в аеротермопресорі $\left(\mathrm{P}_{\mathrm{тп} 2} / \mathrm{P}_{\text {тп1 }}\right)$ від загальної ступені підвищення тиску компресора $\Sigma \pi_{\mathrm{K}}$ :

$$
-\eta_{\mathrm{e}} ; \ldots \ldots \ldots-\left(\mathrm{P}_{\mathrm{Tп2} 2} / \mathrm{P}_{\mathrm{Tп1} 1}\right) \text {; }
$$

1 - схема ГТУ без проміжного охолодження;

2 - схема ГТУ із проміжним охолодженням в поверхневому повітроохолоджувачі; 3 - схема ГТУ iз проміжним охолодженням в аеротермопресорі

В цьому випадку в процесах охолодження 2-3a i 2a-3b (рис. 10) в аеротермопресорах температура повітря на виході буде вищою, ніж при охолодженні в поверхневих повітроохолоджувачах: $\mathrm{T}_{3 \mathrm{a}}>\mathrm{T}_{3}$ (аеротермопресор першого ступеня) $\mathrm{i} \mathrm{T}_{3 \mathrm{~b}}>\mathrm{T}_{3}$ ' (аеротермопресор другого ступеня). Але оскільки тиск повітря за аеротермопресорними ступенями охоло- дження буде дещо вищий $\left(\mathrm{P}_{3 \mathrm{a}}>\mathrm{P}_{3}\right.$ i $\left.\mathrm{P}_{3 b}>\mathrm{P}_{3}{ }^{\prime}\right)$, то площа фігури, яка обмежує процеси циклу із аеротермопресором, буде більшою, тобто

$$
\mathrm{S}_{1-2-3 \mathrm{a}-2 \mathrm{a}-3 \mathrm{~b}-4 \mathrm{a}-5-6}>\mathrm{S}_{1-2-3-2^{\prime}-3^{\prime}-4-5-6}
$$

(1-2-3-2'-3'-4-5-6 відповідає циклу із охолодженням в поверхневих повітроохолоджувачах). Це може свідчити про більшу ефективність циклу та, відповідно, більшому ККД.

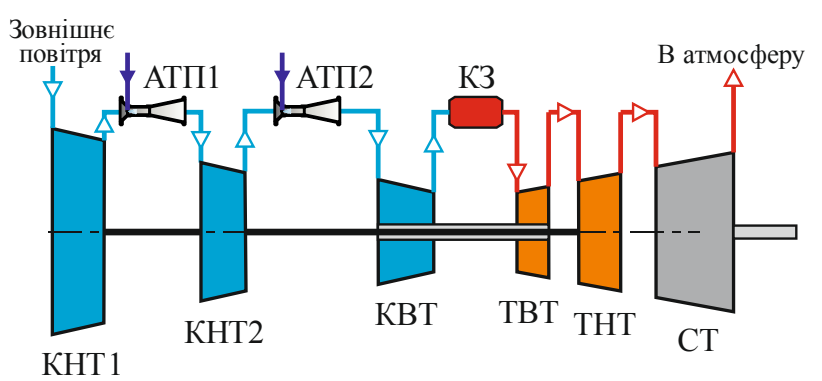

Рис. 9. Схема ГТУ з проміжним охолодженням повітря в аеротермопресорі між ступенями низького середнього та високого тиску в компресорі

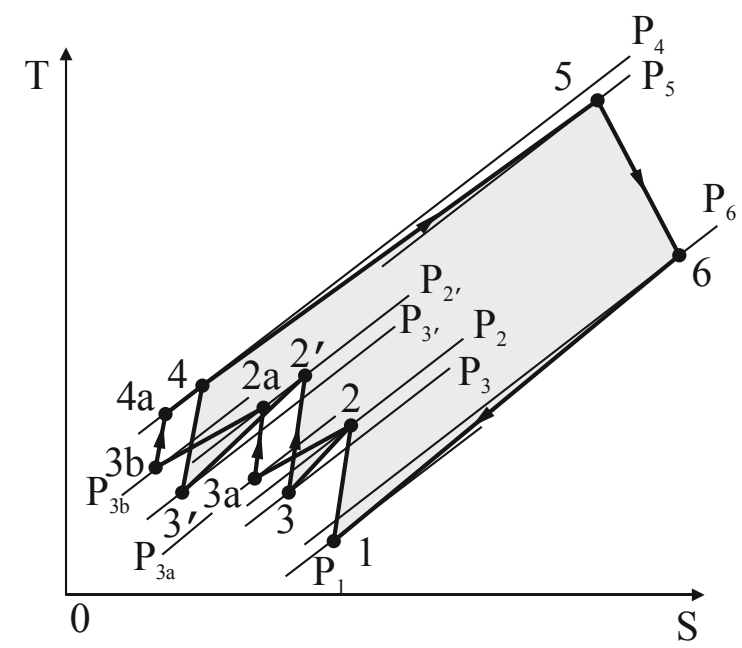

Рис. 10. Термодинамічний цикл ГТУ $з$ проміжним охолодженням повітря в аеротермопресорі між ступенями низького середнього та високого тиску в компресорі

Використання для охолодження циклового повітря аеротермопресора, за рахунок утилізації низькопотенційної теплоти ВЕР, має ряд переваг, а саме:

1) для прискорення повітряного потоку до швидкості, близької звуковій, і випаровування води при мінімальному аеродинамічному опорі використовується тепловий потенціал ВЕР;

2) висока швидкість потоку (біля звукової) забезпечує більш ефективний розпил рідини, ніж в традиційних контактних способах охолодження циклового повітря; 
3) підвищення тиску повітря в аеротермопресорі дозволяє компенсувати аеродинамічні втрати по повітряному тракту і зменшити роботу на стиснення в ступенях компресора;

4) при контактному охолодженні збільшується витрата робочого тіла, i, як наслідок, збільшується потужність ГТУ;

5) аеротермопресор - більш компактний та конструктивно і технологічно простий в порівнянні із традиційними поверхневими повітроохолоджувачами;

6) насичення циклового повітря парами води дозволяє забезпечити екологічне зволоження і, відповідно, зменшення викидів оксидів азоту $\mathrm{NO}_{\mathrm{x}}$.

Впровадження технології охолодження циклового повітря ГТУ аеротермопресорами стримується наступним:

1) відсутністю методології раціонального проектування системи охолодження циклового повітря аеротермопресорами;

2) відсутністю математичної моделі системи термогазодинамічного (аеротермопресорного) охолодження циклового повітря ГТУ;

3) відсутністю достатньої кількості експериментальних даних стосовно особливостей режимів охолодження аеротермопресором при змінних кліматичних умовах.

Вирішення наведених вище задач забезпечить можливість розробляти способи раціональної організації процесів охолодження в аеротермопресорі, що у свою чергу, дозволить досягнути оптимальних параметрів підвищення коефіціснта корисної дії ГТУ та зменшення питомої витрати палива відносно змінних кліматичних умов експлуатації.

Проведений аналіз розглянутих технологій доводить доцільність концепції підвищення паливноенергетичної ефективності ГТУ за допомогою технології проміжного охолодження циклового повітря аеротермопресором, яка полягає у використанні теплового потенціалу ВЕР для прискорення повітряного потоку до швидкості, близької звуковій і випаровування води при мінімальному аеродинамічному опорі.

\section{Висновки}

1. Обгрунтовано підвищення паливноенергетичної ефективності ГТУ за допомогою технології проміжного охолодження циклового повітря аеротермопресором.

2. Застосування аеротермопресора для охолодження циклового повітря дозволяє: забезпечити ефективне дрібно-дисперсне розпилення рідини i, як наслідок, більш ефективне ізотермування процесу в компресорі високого тиску; компенсувати аероди- намічні втрати по повітряному тракту і зменшити роботу на стиснення в ступенях компресора, збільшити витрату робочого тіла, $\mathrm{i}$, як наслідок, збільшити потужність ГТУ.

3. Наведено короткий огляд існуючих технологій підвищення паливно-енергетичної ефективності ГТУ за рахунок проміжного охолодження циклового повітря та наведено переваги технології охолодження аеротермопресором.

\section{Література}

1. Дикий, М. О. Особливості процесу контактного охолодження ииклового повітря в газотурбінних установках та спосіб його реалізаиії [Текст] / М. О. Дикий, А. С. Соломаха // Енергетика: економіка, технології, екологія. - 2012. - № 1. - С. 22-27.

2. Романовський, Г. Ф. Теоретичні основи проектування суднових газотурбінних агрегатів [Текст] / Г. Ф. Романовський, М. В. Ващиленко, С. І. Сербін. - Миколаїв : УДМТУ, 2003. - 304 c.

3. Романовський, Г. Ф. Сучасні газотурбінні агрегати. Том 1. [Текст] / Г. Ф. Романовський, С. І. Сербін, В. М. Патлайчук. - Миколаїв : НУК, 2005. $-344 \mathrm{c}$.

4. Jonsson, M. Humidified gas turbines - a review of proposed and implemented cycles [Text] / M. Jonsson, J. Yan // Energy. - 2005. - № 30. - P. 1013-1078.

5. Коновалов, Д. В. Термопресорні системи охолодження суднових ДВЗ [Текст] / Д. В. Коновалов // Авиационно-космическая техника и технология. - 2011. - № 10 (87). - C. 44-48.

6. Степанов, И. Р. Некоторые задачи движения газа и жидкости в каналах и трубопроводах энергоустановок [Текст] / И. Р. Степанов, В. И. Чудинов. - Ленинград : Наука. Ленингр. отдние, 1977. - 199 с. - (АН СССР, Кольск. филиал им. С. М. Кирова).

7. Дикий, М. О. Підвищення ефективності ГПТУ «Водолій» охолодженням повітряного потоку в компресорі [Текст] / М. О. Дикий, А. С. Соломаха, В. Г. Петренко // Наукові вісті НТУУ КПІ. - 2011. - № 5. - C. 31-34.

8. Boyce, M. P. Gas Turbine Engineering Handbook [Text] / M. P. Boyce. - Houston, Texas : Gulf Publishing Company, 2002. - 801 p.

9. Соколов, Е. Я. Струйные аппараты [Текст] / Е. Я. Соколов, Н. М. Зингер. - Москва : Энергоатомиздат, 1989. - 352 c.

10. Радченко, М. І. Аналіз ефективності проміжного охолодження повітря газотурбінних установок упорскуванням води аеротермопресором [Текст] / М. І. Радченко, Д. В. Коновалов, Г. О. Ко- 
балава // Авіаційно-космічна техніка і технологія. - 2017. - № 4 (139). - C. 106-111.

\section{References}

1. Dykyy, M. O, Solomakha, A. S. Osoblyvosti protsesu kontaktnoho okholodzhennya tsyklovoho povitrya $\mathrm{v}$ hazoturbinnykh ustanovkakh ta sposib yoho realizatsiyi [Features of the contact cooling process of cyclic air in gas turbine plants and the way of its realization]. Enerhetyka: ekono-mika, tekhnolohiyi, ekolohiya, 2012, no. 1, pp. 22-27.

2. Romanovs'kyy, H. F., Vashchylenko, M. V., Serbin, S. I. Teoretychni osnovy proektuvannya sudnovykh hazoturbinnykh ahrehativ [Theoretical bases of the ship gas-turbine aggregates designing]. Mykolayiv, UDMTU Publ., 2003. 304 p.

3. Romanovs'kyy, H. F., Serbin, S. I., Patlaychuk, V. M. Suchasni hazoturbinni ahrehaty. Tom 1. [Modern gas turbine units]. Mykolayiv, NUK Publ., 2005. $344 \mathrm{p}$.

4. Jonsson, M., Yan, J. Humidified gas turbines a review of proposed and implemented cycles. Energy, 2005, no. 30, pp. 1013-1078.

5. Konovalov, D. V. Termopresorni systemy okholodzhennya sudnovykh DVZ [The thermopressor systems of cooling air of engine ships]. Aviacijnokosmicna tehnika i tehnologia - Aerospace technic and technology, 2011, no. 10 (87), pp. 44-48.
6. Stepanov, I. R., Chudinov, V. I. Nekotorye zadachi dvizheniya gaza i zhidkosti v kanalakh i truboprovodakh energoustanovok [Some problems of the gas and liquid motion in the channels and pipelines of power plants]. Leningrad, The Science Publ., Leningrad department, 1977. 199 p.

7. Boyce, M. P. Gas Turbine Engineering Handbook. Houston, Texas, Gulf Publishing Company, 2002. $801 \mathrm{p}$.

8. Dykyy, M. O., Solomakha, A. S., Petrenko V. H. Pidvyshchennya efektyvnosti HPTU "Vodoliy" okholodzhennyam povitryanoho potoku $\mathrm{v}$ kompresori [Increased efficiency GSTP "Vodoliy" by cooling air stream in the compressor]. Naukovi visti NTUU KPI, 2011, no. 5, pp. 31-34.

9. Sokolov, E. Ja., Zinger, N. M. Strujnye apparaty [Jet Apparatuses]. Moscow, Jenergoatomizdat Publ., 1989. 352 p.

10. Radchenko, M. I, Konovalov, D. V., Kobalava H. O. Analiz efektyvnosti promizhnoho okholodzhennya povitrya hazoturbinnykh ustanovok uporskuvannyam vody aerotermopresorom [Analysis of the intermediate air cooling of gas-turbine plants by aerothermopressor water injection]. Aviacijno-kosmicna tehnika i tehnologia - Aerospace technic and technology, 2017, no. 4 (139), pp. 106-111.

Поступила в редакцию 2.02.2018, рассмотрена на редколлегии 14.02.2018

\section{ПРОМЕЖУТОЧНОЕ ОХЛАЖДЕНИЕ ЦИКЛОВОГО ВОЗДУХА ГАЗОТУРБИННЫХ УСТАНОВОК АЭРОТЕРМОПРЕССОРОМ}

\section{Д. В. Коновалов, Г. А. Кобалава}

Проведен анализ существующих технологий повышения топливно-энергетической эффективности газотурбинных установок за счет промежуточного охлаждения циклового воздуха и обозначены преимущества технологии охлаждения аэротермопрессором. Применение данного аппарата для охлаждения компрессорного воздуха позволяет компенсировать аэродинамические потери по воздушному тракту и уменьшить работу на сжатие в компрессоре, увеличить расход рабочего тела и, как следствие, увеличить мощность ГТУ. Определены задачи, решение которых обеспечит возможность рациональной организации процессов охлаждения в аэротермопрессоре, что, в свою очередь, позволит достичь оптимальных параметров повышения коэффициента полезного действия ГТУ и уменьшения удельного расхода топлива относительно переменных климатических условий эксплуатации.

Ключевые слова: газотурбинная установка, охлаждение циклового воздуха, термогазодинамическая компрессия, аэротермопрессор.

\section{INTERCOOLING OF THE GAS TURBINE PLANT CYCLIC AIR WITH AN AEROTHERMOPRESSOR}

\section{Konovalov, H. Kobalava}

Existing technologies to improve the fuel and energy efficiency of gas turbine plants due to intercooling of the cycle air are analyzed. One of the promising ways for increasing the efficiency of such technologies is using thermogasdynamic compression in the heat recovery processes of secondary energy resources. A feature of this process 
is the pressure rate increase due to the instant evaporation of a finely dispersed liquid is injected into the air stream which accelerated to the speed of sound. When the pressure of the boiling liquid is increased, the power consumption for compressing the working fluid (cyclic air) is reduced, the efficiency is increased and the consumption of the fuel and energy resources of the gas turbine plant is reduced.

The advantages of cooling technology with an aerothermopressor are outlined in the article. The aerothermopressor is a multifunctional jet apparatus, whose work consists in injecting water into the stream of cyclic air when it is compressed in the gas turbine plant compressor. If this apparatus is used for cooling of cycle air, it will be compensate for aerodynamic losses along the air path and it will reduce compression work in the compressor, increase the consumption of the working fluid and, as a result, increase the gas turbine plant power. The basic schemes of the aerothermopressor installation between the stages of low and high pressure compressors are considered. Theoretical thermodynamic cycles of such gas turbine plants are presented and the advantage of using a contact cooler for intercooling of the cyclic air in comparison with surface air coolers for intercooling is defined in this paper.

The proposed cooling technology makes it possible using low-potential heat of secondary energy resources of gas turbine plants (heat of cyclic air), the utilization of which by traditional methods is problematic because the temperature of waste heat sources is low.

The tasks are determined, the solution of which will ensure the possibility of rational organization of cooling processes in the aerothermopressor, which in turn will allow achieving optimal parameters for increasing the efficiency of the gas turbine plant and reducing the specific fuel consumption in relation to the variable climatic conditions of operation.

Keywords: gas turbine plant, cooling of cyclic air, thermogasdynamic compression, aerothermopressor.

Коновалов Дмитро Вікторович - канд. техн. наук, доцент кафедри теплотехніки, Херсонська філія Національного університету кораблебудування імені адмірала Макарова, Херсон, Україна, e-mail: dimitriyko79@gmail.com.

Кобалава Галина Олександрівна - аспірант кафедри кондиціювання та рефрижерації, Національний університет кораблебудування імені адмірала Макарова, Миколаїв, Україна, e-mail: g.lavamay@gmail.com.

Konovalov Dmytro - PhD, associate professor of the Thermal Engineering department, The Kherson Branch of the Admiral Makarov National University of Shipbuilding, Kherson, Ukraine, e-mail: dimitriyko79@gmail.com.

Kobalava Halina - PhD student of the Air Conditioning and Refrigeration department, Admiral Makarov National University of Shipbuilding, Mykolaiv, Ukraine, e-mail: g.lavamay@gmail.com. 